\title{
Nutrient limits in diets for growing dairy goats
}

\author{
Límites nutricionales para dietas de cabras lecheras en crecimiento
}

\author{
AL Martínez-Marín*, M Pérez-Hernández, LM Pérez-Alba, D Carrión-Pardo, AG Gómez-Castro \\ Departamento de Producción Animal, Universidad de Córdoba, España.
}

\begin{abstract}
RESUMEN
El objetivo del presente trabajo fue revisar el consumo de materia seca y las necesidades nutritivas de cabras lecheras de reposición estabuladas para establecer límites nutricionales aplicables a la formulación de dietas por programación lineal a mínimo coste. El diseño de dietas nutricionalmente adecuadas y económicas requiere que el nutricionista estime correctamente el consumo de materia seca y forraje y los aportes y las necesidades de nutrientes. La bibliografía revisada sugiere que el consumo total de materia seca de las cabras oscila entre los límites físico y fisiológico impuestos por la capacidad del tracto digestivo y las necesidades energéticas diarias. El efecto de llenado digestivo puede relacionarse con los carbohidratos estructurales de la dieta, mientras la saciedad metabólica se relaciona con la concentración energética de la dieta. El consumo mínimo de forraje necesario para mantener la salud ruminal es bajo, mientras que el consumo máximo de forraje está determinado probablemente por el contenido de fibra neutrodetergente de la dieta. Los aportes y las necesidades de energía y proteína calculadas según los dos sistemas de valoración más modernos son similares, por lo que es indistinto usar cualquiera de ambos para optimizar dietas. Las propuestas recientes para el cálculo de los aportes y las necesidades de calcio y fósforo ofrecen una mayor precisión.
\end{abstract}

Key words: goat feeding, feed formulation, feeding standards.

Palabras clave: nutrición caprina, optimización de dietas, sistemas de alimentación.

\section{INTRODUCTION}

Proper nutrition of growing goats is essential to ensure the future productivity of dairy goat herds. It is well known that deficit or excess of nutrients during growth has a negative effect on the production traits of females at maturity (Owens et al 1993). On the other hand, diets for growing goats fed in confinement should be cheap and easy handling (Martínez Marín 2007).

Nutritionists can design satisfactory diets using minimum cost linear programming. The use of linear programming requires building a feed formulation matrix and setting appropriate nutrient limits. The nutritive value of the feedstuffs included in the feed formulation matrix can be obtained from tables or calculated from the equations published by different institutions that have proposed feed evaluation systems for goats: Institut National de la Recherche Agronomique (INRA 1978, 1988, 2007) Agricultural and Food Research Council (AFRC 1993, 1998), National Research Council (NRC 1981, 2007), etc. Nutrient requirements of growing goats, based on their weight, growth rate, and physiological stage can be obtained also from tables or calculated with the equations proposed by the aforementioned institutions.

Accepted: 18.08.2011.

* Departamento de Producción Animal, Campus Universitario de Rabanales, Carretera Madrid-Cádiz, km. 396, 14014 Córdoba, España; pa1martm@uco.es
Mohr (1972) showed that diet optimization by linear programming applying a fixed energy content, i.e. for a fixed intake, does not result necessarily in the most economic solution on a daily basis (unit price $\mathrm{x}$ units consumed in a day), because it does not take into account the actual intake capacity of the animal. In order to obtain solutions optimized on a daily basis, it is necessary to set limits in the optimization matrix according to the estimated range of dry matter intake (DMI). This method is interesting to design diets for housed growing goats when the quality, availability or price of forage prevents the use of high forage diets. According to Hadjipanayiotou and MorandFehr (1991), feeding ruminants with high concentrate diets can be cheaper than feeding them with high forage diets in areas where availability of good quality forages is limited.

The aim of this work was to review DMI and nutrient requirements of growing dairy goats and derive proper nutrient limits to optimize diets through minimum cost linear programming.

\section{DRY MATTER INTAKE}

Conrad et al (1964) and Montgomery and Baumgardt $\left(1965^{\mathrm{ab}}\right)$ showed that DMI depends on physiological (energy requirements), and physical (capacity of the digestive system, especially the rumen) factors. Dry matter intake needed to meet the energy requirements is determined by the physiological stage and depends on the energy density of the diet. Dry matter intake limited by the capacity of the digestive system is determined by the size of the 
abdominal cavity, and it depends on the volume of the diet, which can be related to its neutral detergent fibre (NDF) content (Williams et al 1989). For a specific diet offered ad-libitum, current DMI is equivalent to the amount that meets the daily energy requirements or that completely fills the alimentary tract whichever is reached first. It is now well known that DMI control depends on several factors and not only on metabolic and physiological ones (Forbes 2007). Nevertheless, the proposals of Conrad et al (1964) and Montgomery and Baumgardt $\left(1965^{\mathrm{a}, \mathrm{b}}\right)$ have provided a useful worksheet to estimate approximate DMI limits of ruminant animals.

Dry matter intake observed by different authors in housed growing goats provides evidence for the existence of physiological and metabolic controls of DMI in those animals. Dry matter intake of growing goats reaches a physiological limit when the metabolizable energy (ME) content of the diet is about $12.55 \mathrm{MJ} / \mathrm{kg} \mathrm{DM}$. Lu and Potchoiba (1990) supplied three complete pelleted diets, which had increasing levels of ME $(10.29,11.59$ and $12.76 \mathrm{MJ} / \mathrm{kg} \mathrm{DM}$ ), to goats between 4 and 8 months old, and they observed that DMI decreased nonlinearly with increasing ME concentration: The intake decreased 124 $\mathrm{g} / \mathrm{d}$ when dietary ME content increased from 10.29 to $11.59 \mathrm{MJ} / \mathrm{kg}$ DM (i.e. $95 \mathrm{~g}$ less DMI per each MJ of ME increment in the diet); but increasing dietary ME content from 11.59 to $12.76 \mathrm{MJ} / \mathrm{kg}$, decreased the intake $326 \mathrm{~g} / \mathrm{d}$ (i.e. $278 \mathrm{~g}$ less per each $\mathrm{MJ}$ of $\mathrm{ME}$ increment in the diet). Goetsch et al (2003) compared five diets, comprised of hay offered ad-libitum and concentrate offered separately in different amounts (25, 50 and $75 \%$ of the diet, $2 \%$ body weight, and ad-libitum), supplied to goats from 3.5 to 7 months old. These authors found that the ME of the diet consumed by the animals when they had free access to hay and concentrate was $12.72 \mathrm{MJ} / \mathrm{kg} \mathrm{DM}$, but there were no differences in DMI among the five diets.

On the other hand, literature also suggests that growing goats have a physical intake limit. In the study of Hooper and Welch (1983), 3- and 9-month old goat kids reached a maximum intake of 21 and $33 \mathrm{~g} \mathrm{NDF} / \mathrm{kg}$ per $\mathrm{kg}$ metabolic body weight $\left(\mathrm{BW}^{0.75}\right)$, respectively, when supplied a diet comprised of grass hay offered ad-libitum and concentrate offered at $0.225 \mathrm{~kg} / \mathrm{d}$. Randy et al (1984) observed an intake of $0.75 \mathrm{~kg} \mathrm{DM} / \mathrm{d}$ or $22 \mathrm{~g} \mathrm{NDF} / \mathrm{kg} \mathrm{BW}^{0.75}$ in 1 -year old goats fed ad-libitum a diet, comprised of grass hay and concentrate, that contained $24.7 \%$ acid detergent fibre (ADF). Brown and Johnson (1985) fed diets, that included 35 and $65 \%$ chopped wheat straw (24 and $40 \%$ $\mathrm{ADF}$ in the diet, respectively), to 3-month old goats and observed the intake of 0.58 and $0.52 \mathrm{~kg} \mathrm{DM} / \mathrm{d}$ or 20 and $27 \mathrm{~g} \mathrm{NDF} / \mathrm{kg} \mathrm{BW}^{0.75}$, respectively. Goetsch et al (2003) reported an average intake of wheat hay, included in the diet up to $75 \%$, of $0.461 \mathrm{~kg} \mathrm{DM} / \mathrm{d}$ equivalent to $32 \mathrm{~g} \mathrm{NDF} /$ $\mathrm{kg} \mathrm{BW}^{0.75}$. Urge et al (2004) observed in goats between 4 and 7 months old that the average intake was $0.75 \mathrm{~kg}$ $\mathrm{DM} / \mathrm{d}$ or $27 \mathrm{~g} \mathrm{NDF} / \mathrm{kg} \mathrm{BW}^{0.75}$ when fed a diet including
$50 \%$ concentrate. Lu et al (2005) noted that maximum gut fill in growing goats could be reached when the diet contained more than $26 \%$ ADF on a DM basis, but they recommended a maximum content of $24 \% \mathrm{ADF}$ in the diet to prevent inadequate intake.

Leroy (1974) proposed "volume coefficients", minimum and maximum, for the diets of domestic animals according to their physiological stage. The proposal was based on the concept that a diet that is too bulky prevents enough intake to meet nutrient requirements and, on the contrary, prevents the normal functioning of the digestive system when it is excessively concentrated. The values presented in Table 1 suggest that the DMI calculated according to different authors is about within Leroy's range estimates.

INRA (1988) and AFRC (1998) pointed out that calculated DMI should be decreased by $10 \%$ during the last month of pregnancy. When designing diets, such decrease could be even higher as a safety measure to prevent inadequate nutrient intake, especially when dams carry multiple foetuses and poor quality forage is supplied. The decreased appetite observed in the weeks prior to parturition (Fedele et al 2000) could be explained by the

Table 1. Daily dry matter intake of young goats at three ages. Consumo diario de materia seca en cabritas a tres edades.

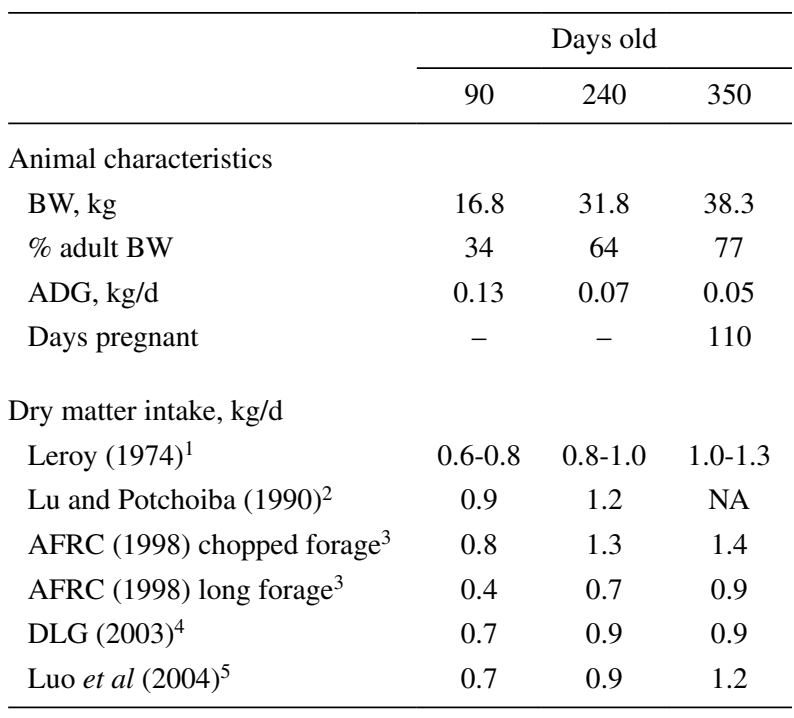

$\mathrm{BW}$, body weight; $\mathrm{ADG}$, average daily gain; NA, not available. From volume coefficients recommended by the author. If the acid detergent fibre content of the diet is $24 \%$.

If the metabolisability of the diet is 0.55 .

If the metabolizable energy (ME) content of the diet is 10.75 $\mathrm{MJ} / \mathrm{kg}$.

5 If the diet contains $10.75 \mathrm{MJ} \mathrm{ME} / \mathrm{kg}$ and $14 \%$ crude protein.

BW, peso vivo; ADG, crecimiento medio diario; NA, no disponible. A partir de los coeficientes de volumen recomendados por el autor. $\mathrm{Si}$ el contenido de fibra acidodetergente de la dieta es $24 \%$. Si la metabolicidad de la dieta es 0.55 .

Si el contenido de energía metabolizable (EM) de la dieta es 10,75 $\mathrm{MJ} / \mathrm{kg}$.

5 Si la dieta contiene 10,75 MJ EM/kg y $14 \%$ de proteína bruta. 
competition for abdominal space between rapidly growing conceptus and digestive tract, and metabolic and endocrine factors (Forbes 2007).

\section{FORAGE INTAKE}

Bas et al (1991) recommended including $20 \mathrm{~g}$ forage/ $\mathrm{kg} \mathrm{BW}^{0.75}$ in the diet of weaning goat kids to ensure proper rumen function. In the work of Randy et al (1984), goats consumed $0.16 \mathrm{~kg} \mathrm{DM} / \mathrm{d}(22 \%$ diet DM) of grass hay, equivalent to $12 \mathrm{~g} / \mathrm{kg} \mathrm{BW}{ }^{0.75}$, and $\mathrm{ADG}$ was $0.12 \mathrm{~kg} / \mathrm{d}$. Goetsch et al (2003) reported no differences in ADG ( $75 \mathrm{~g} / \mathrm{d}$ on average) when wheat hay intake was between 0.13 and $0.30 \mathrm{~kg} / \mathrm{d}$ (20 and $50 \%$ of the diet, respectively) equivalent to 14 and $32 \mathrm{~g} / \mathrm{kg} \mathrm{BW}^{0.75}$.

INRA (1978) suggested figures of maximum forage intake, e.g. 45 and $60 \mathrm{~g} / \mathrm{kg} \mathrm{BW}^{0.75}$ for wheat straw and oat and alfalfa hay, respectively. Forage intake depends on its own chemical and nutritional characteristics and the quantity and composition of the supplement. INRA (2007) provides a detailed explanation of forage intake calculation considering both factors.

The inclusion of low quality hays and crop residues in the diet of ruminants is an alternative to good quality forage when it is scarce (Susmel et al 1989). Masson et al (1991) cited a straw consumption by adult goats in mid lactation from 0.3 to $0.8 \mathrm{~kg} / \mathrm{d}$, according to its quality; those figures would provide 20 to $50 \%$ maintenance energy requirements. It can be calculated that wheat straw (6.28 MJ ME/kg DM; NRC 2007) supplied 29 and 48\% maintenance energy requirements (4.44 MJ ME/d; NRC 2007 ) in the 35 and $65 \%$ wheat straw diets from the work of Brown and Johnson (1985).

\section{PREDICTION OF BODY WEIGHT, GROWTH RATE, AND FOETAL DEVELOPMENT}

To calculate nutrient requirements, body weight (BW) and growth rate (ADG) must be known. According to Freitas (2005), the monomolecular model of Brody (1926) can be applied to describe the growth rate of goats. Using $3.2 \mathrm{~kg} \mathrm{BW}$ at birth, $50 \mathrm{~kg}$ adult $\mathrm{BW}$, eight months and $55 \%$ adult $\mathrm{BW}$ at first mating, and thirteen months and $75 \%$ adult $\mathrm{BW}$ at parturition as input values in the model (INRA 1988), the following functions can be obtained: $\mathrm{BW}(\mathrm{kg})=50 \times\left[1-0.95 \times \mathrm{e}^{(-0.004 \times \mathrm{age})}\right]$, and $\mathrm{ADG}(\mathrm{kg} / \mathrm{d})=50 \times 0.95 \times 0.004 \times \mathrm{e}^{(-0.004 \times \text { age })}$; where age is days from birth. These functions predict that the goat will have 16.9, 31.8 and $38.3 \mathrm{~kg} \mathrm{BW}$ and an ADG of $0.13,0.07$ and $0.05 \mathrm{~kg} / \mathrm{d}$ at 90, 240 and 350 days old, respectively. Although these figures are only approximate values, they can be useful to calculate nutrient requirements at a given age in the absence of more accurate data obtained in vivo.

If growing goats are pregnant, it is necessary to know foetal growth and litter weight to calculate nutrient deposition in the conceptus. AFRC (1998) derived nutrient deposition in the conceptus from data of foetal growth obtained with sheep (Robinson et al 1977, McDonald et al 1979, ARC 1980) and estimated mean birth weights of 4.44, 3.95 and $3.65 \mathrm{~kg}$ for single, twin and triplet kids, respectively, in British Saanen goats. CSIRO (2007) also calculated conceptus growth rate in goats from the sheep equations of ARC (1980). In addition, litter weight can be roughly estimated from the sheep equations of ARC (1980). Alternatively, DLG (2003) published equations that describe the course of foetal development during the last third of pregnancy from data obtained by Voicu et al (1993) in Carpathian goats.

\section{ENERGY}

The energy requirements of growing goats at three ages calculated according to different feed evaluation systems are shown in Table 2. All systems use the factorial method, i.e. total energy requirements are calculated by adding the requirement for each body function (maintenance, growth, pregnancy, etc). DLG (2003) calculates the lowest energy requirements for pregnant goats compared with other systems because does not take into account energy requirements for conceptus growth before the fifth month of pregnancy.

The most recent energy evaluation systems for goats are INRA (2007) and NRC (2007). INRA (2007) expressed the energy supply and requirements as milk feeding units (UFL), which is the net energy of lactation (NEL) content of the particular feedstuff relative to that of the French reference barley (7.11 MJ NEL/kg as fed). The energy content of the feedstuffs can be calculated using the set of equations published (INRA 2002, 2007). The calculations include the estimation of gross energy (GE), digestible organic matter, DE, ME:DE ratio and efficiency of use of ME for milk production (kl). Finally, the NEL value is divided by 7.11 to express it as UFL. $\mathrm{Kl}$ is calculated relative to metabolisability $(\mathrm{Qm} ; \mathrm{Qm}=\mathrm{ME}: \mathrm{GE})$ as in the equation: $\mathrm{kl}=0.60+0.24 \mathrm{x}(\mathrm{Qm}-0.57)$.

NRC (2007) expresses the energy supply and requirements as ME. The ME content of the feedstuffs is calculated from the total digestible nutrients (TDN) content using the relationship: $1 \mathrm{~kg}$ TDN $=18.37 \mathrm{MJ} \mathrm{DE}$ $=15.06 \mathrm{MJ}$ ME . The TDN content is calculated from regression equations or digestibility coefficients applicable to crude protein $(\mathrm{CP})$, crude fibre, crude fat and nitrogen free extractives.

Each feed evaluation system calculates the energy supply and requirements of the domestic animals in a different way that can affect the cost of the diets designed according to their recommendations. Studies in pigs (Schinkel et al 2008), horses (Martínez Marín 2009), and dairy cows (Martínez Marín et al 2010 ) show that the differences among the compared systems are due to the estimated energy requirements, the energy content of feedstuffs or both. However, Martínez Marín et al $\left(2010^{\mathrm{b}}\right)$ found that 
the use of INRA (2007) or NRC (2007) to optimize diets for growing goats through minimum cost linear programming does not affect significantly to their cost, which was justified by the similar evaluation of energy supply and requirements in both systems.

Regardless of the system used, the limits applied to energy when optimizing diets through minimum cost linear programming can be expressed in relation to the calculated range of DMI. Thus, the minimum and maximum energy limits will correspond to the energy concentration that meets daily requirements when DMI is maximum and minimum, respectively. Moreover, meeting the nutrient requirements other than energy can be guaranteed by expressing their inclusion in the diet in relation to the energy required (Martínez Marín et al 2010 ${ }^{\mathrm{b}}$ ). Diets optimized with this procedure meet daily nutrient requirements at the lowest possible cost under the proposal of Mohr (1972). The daily amount of diet to be supplied to the animals will be within the minimum and maximum DMI and is the result of dividing the daily energy requirements by the energy content of the diet.

\section{PROTEIN}

Table 2 shows the metabolizable protein requirements of growing goats at three ages calculated according to different feed evaluation systems. All systems use the factorial method, and the figures are rather similar between them except for pregnant goats, which suggests a different evaluation of protein requirements for gestation. The lowest figures of AFRC (1998) and DLG (2003) can be due to the figure 0.85 used by AFRC (1998) for the efficiency of utilization of metabolizable protein (MP) for the growth of the conceptus, whereas DLG (2003) considers negligible the protein requirements for the growth of the conceptus prior to the fifth month of gestation.

The most recent protein evaluation systems for goats are INRA (2007) and NRC (2007). INRA (2007) expresses the

Table 2. Nutrient requirements of young goats at three ages.

Necesidades nutritivas diarias de cabritas a tres edades.

\begin{tabular}{|c|c|c|c|c|c|c|}
\hline \multirow{3}{*}{$\begin{array}{l}\text { Requirements } \\
\text { Energy and protein }\end{array}$} & \multicolumn{6}{|c|}{ Days old } \\
\hline & \multicolumn{2}{|c|}{90} & \multicolumn{2}{|c|}{240} & \multicolumn{2}{|c|}{350} \\
\hline & $\begin{array}{c}\mathrm{ME} \\
\mathrm{MJ} / \mathrm{d}\end{array}$ & $\begin{array}{l}\mathrm{MP} \\
\mathrm{g} / \mathrm{d}\end{array}$ & $\begin{array}{c}\mathrm{ME} \\
\mathrm{MJ} / \mathrm{d}\end{array}$ & $\begin{array}{l}\text { MP } \\
\mathrm{g} / \mathrm{d}\end{array}$ & $\begin{array}{c}\mathrm{ME} \\
\mathrm{MJ} / \mathrm{d}\end{array}$ & $\begin{array}{l}\text { MP } \\
\mathrm{g} / \mathrm{d}\end{array}$ \\
\hline $\operatorname{AFRC}(1998)^{1}$ & 7.20 & 50 & 9.20 & 45 & 11.51 & 53 \\
\hline DLG $(2003)^{2}$ & 7.11 & 50 & 9.00 & 56 & 9.41 & 57 \\
\hline NRC (2007) & 7.49 & 63 & 8.79 & 61 & 11.21 & 126 \\
\hline INRA $(2007)^{3,4}$ & 6.53 & 57 & 8.66 & 51 & 10.84 & 107 \\
\hline Calcium and phosphorus & $\begin{array}{l}\mathrm{Ca} \\
\mathrm{g} / \mathrm{d}\end{array}$ & $\begin{array}{c}\mathrm{P} \\
\mathrm{g} / \mathrm{d}\end{array}$ & $\begin{array}{l}\mathrm{Ca} \\
\mathrm{g} / \mathrm{d}\end{array}$ & $\begin{array}{c}\mathrm{P} \\
\mathrm{g} / \mathrm{d}\end{array}$ & $\begin{array}{l}\mathrm{Ca} \\
\mathrm{g} / \mathrm{d}\end{array}$ & $\begin{array}{c}\mathrm{P} \\
\mathrm{g} / \mathrm{d}\end{array}$ \\
\hline AFRC (1998) & 4.2 & 2.5 & 2.8 & 2.1 & 3.4 & 2.5 \\
\hline DLG (2003) & 3.1 & 1.9 & 2.5 & 1.7 & 3.5 & 2.3 \\
\hline NRC (2007) & 4.7 & 2.4 & 3.5 & 2.0 & 4.7 & 2.6 \\
\hline INRA $(2007)^{5}$ & 6.7 & 3.0 & 5.7 & 3.4 & 8.8 & 4.5 \\
\hline Meschy $\left(2002^{\mathrm{a}}\right)$ & 6.5 & 2.3 & 4.7 & 1.9 & 7.6 & 2.7 \\
\hline
\end{tabular}

ME, metabolizable energy; MP, metabolizable protein.

$\dagger$ When it was necessary for calculations, dry matter intake figures used were $0.7,0.9$ and $1.0 \mathrm{~kg} / \mathrm{d}$ at 90, 240 and 350 days old, respectively.

If the metabolisability of the diet is 0.55 .

MP requirements are net requirements multiplied by 1.43 .

INRA (2007) expresses the energy requirements as milk fodder units (UFL); to make comparison easy, ME has been calculated as 1 UFL $=7.11$

MJ net energy of lactation, and efficiency of use of ME for lactation $=0.59$.

4 INRA (2007) expresses protein requirements as protein truly digested in the small intestine (PDI), which is the same as MP.

5 INRA (2007) expresses the requirements as net values, the absorption coefficients ( 0.3 and 0.7 for calcium and phosphorus) proposed by Meschy $\left(2002^{\mathrm{a}}\right)$ have been used to make comparison easier.

EM, energía metabolizable; PM, proteína metabolizable.

$\dagger$ En los cálculos del consumo de materia seca se utilizaron los valores 0,7, 0,9 y 1,0 kg/d a 90, 240 y 350 días de edad, respectivamente. Si la metabolicidad de la dieta es 0,55 .

Las necesidades de PM se calculan como las necesidades netas multiplicadas por 1,43.

INRA (2007) expresa las necesidades de energía como unidades forrajeras leche (UFL); para facilitar la comparación, la EM se ha calculado como $1 \mathrm{UFL}=7,11 \mathrm{MJ}$ de energía neta de lactación, y la eficiencia de utilización de la EM para lactación = 0,59.

4 INRA (2007) expresa las necesidades de proteína como proteína realmente digestible en el intestino delgado (PDI), que es equivalente a la PM.

5 INRA (2007) expresa las necesidades como valores netos, se han utilizado los coeficientes de absorción (0,3 y 0,7 para el calcio y el fósforo) propuestos por Meschy $\left(2002^{\mathrm{a}}\right)$ para facilitar la comparación. 
protein supply and requirements as protein truly digested in the small intestine (PDI). The PDI content of the feedstuffs is the amount of microbial protein synthesized in the rumen (PDIMN or PDIME) plus rumen undegradable feed protein (PDIA) that is digested in the small intestine. The value of PDIME and PDIMN depends on microbial protein yield when energy or nitrogen available in the rumen limits microbial growth, respectively. For each feedstuff two PDI values $($ PDIE = PDIME + PIDA and PDIN = PDIMN + PIDA) are calculated; the actual PDI content of the whole diet is the minor of both. PDIME, PDIMN and PIDA values are calculated from the organic matter that can be digested in the rumen and the $\mathrm{CP}$ content of the feedstuffs, using the appropriate coefficients INRA (2002, 2007).

NRC (2007) calculates the MP of feedstuffs as a constant proportion of the $\mathrm{CP}$ content, based on the indications of NRC (2000) that MP accounts for 64 to $80 \%$ of the $\mathrm{CP}$ of the ration for undegradable protein (UIP) contents between 0 and $100 \%$. Degradable protein (DIP) content is calculated as the difference between the MP and UIP.

Martínez Marín et al $\left(2010^{b}\right)$ found no differences in the PDI and MP content of the diets optimized in their work. This is expected because both values are the same concept in practice: The amount of true protein that is digested in the small intestine. However, the similarity is remarkable bearing in mind the simple calculations of NRC (2007) vs. the complex ones of INRA (2002, 2007), which take into account the relationship between energy and nitrogen in the rumen and the digestibility of the protein that enters the small intestine similar to other protein evaluation systems (AFRC 1993, Hvelplund and Madsen 1993, NRC 2001).

The results obtained by Negesse et al (2001) in postweaned goat kids show that inadequate or excessive inclusion of $\mathrm{CP}$ in the diet results in inefficient use of nitrogen intake. In that respect, both INRA (2007) and NRC (2007) take into account the negative effect of inadequate available nitrogen in relation to energy on ruminal digestion. INRA (2007) recommended that the PDIN-PDIE difference should not be less than $-14 \mathrm{~g} / \mathrm{UFL}$ in animals fed up to 1.5 times the maintenance energy requirements to keep the efficiency of ruminal digestion, assuming that the shortage of available nitrogen in the rumen is covered by the recycling of endogenous urea. The shortage can be prevented by setting a lower limit of the PDIN:PDIE ratio equal to unity when optimizing diets. NRC (2007) recommended that the relationship DIP:TDN should be higher than 0.09. This recommendation is based on the works of Prieto et al (2000) and Soto-Navarro et al (2003, 2004). Prieto et al (2000) observed satisfactory ADG of wether goats between 4 and 12 months old offered a 70\% concentrate diet with $14 \% \mathrm{CP}$ and a DIP:TDN ratio equal to 0.115 . In yearling wether goats offered a maize based diet, Soto-Navarro et al (2003) found that a 9-10\% CP content and a DIP:TDN ratio equal to 0.073 was enough to maximize microbial protein synthesis, though organic matter digestibility increased when the $\mathrm{CP}$ content and the DIP:TDN ratio was $11.5 \%$ and 0.104 or $13.5 \%$ and 0.114 . Soto-Navarro et al (2004) observed satisfactory ADG of wether goats between 7 and 14 months old offered a $70 \%$ concentrate diet with $13 \% \mathrm{CP}$ and a DIP:TDN ratio equal to 0.09 .

\section{CALCIUM AND PHOSPHORUS}

The requirements of calcium $(\mathrm{Ca})$ and phosphorus $(\mathrm{P})$ calculated for growing goats at three ages according to different feed evaluation systems are shown in Table 2. All systems use the factorial method. Calcium requirements calculated according to Meschy (2002 $)$ and INRA (2007) are much higher due to the low absorption coefficient used (from Meschy 2002 ${ }^{\mathrm{a}}$ ): 0.30 vs. $0.55,0.65$ and 0.45 in AFRC (1998), DLG (2003) and NRC (2007), respectively. By contrast, the higher $\mathrm{P}$ requirements calculated according to INRA (2007) are due to the high net requirements as the absorption coefficient used (from Meschy 2002a) is similar to that of other systems: 0.70 vs. $0.64,0.80$ and 0.65 in AFRC (1998), DLG (2003) and NRC (2007), respectively. The $\mathrm{Ca}$ and $\mathrm{P}$ supply and requirements of domestic ruminants and specifically goats have been reviewed in depth by Meschy $\left(2002^{\mathrm{ab}}\right)$ and Meschy and Corrias (2005). Meschy $\left(2002^{\mathrm{b}}\right)$ estimated that the greater accuracy resulting from his recommendations would allow a decrease of $20-25 \%$ in the $\mathrm{P}$ content of manure, which would have environmental benefits.

The maximum content of $\mathrm{Ca}$ and $\mathrm{P}$ in the diet recommended by NRC (2005) is 1.5 and $0.6 \%$ DM, respectively. The requirements of $\mathrm{Ca}$ and $\mathrm{P}$ are interrelated, but the tolerable limits of the Ca:P ratio are large. ARC (1980) and NRC (1981) recommended a minimum limit of 1:1 and 1.2:1, respectively, while the maximum recommended limit is 7:1 (ARC 1980, NRC 1980). Liesegang and Risteli (2005) found no differences in bone characteristics of 8-month old goats fed diets with adequate levels of $\mathrm{P}$ and $\mathrm{Ca}: \mathrm{P}$ ratios of 1.5:1 and 4:1. Moreover, Mejia-Haro et al (2001) found no differences in the apparent absorption and retention of $\mathrm{P}$ in 6-month old lambs fed a diet slightly deficient in $\mathrm{P}$ and $\mathrm{Ca}: \mathrm{P}$ ratios of 2.5:1.5, 6:1 and 9:1. However, Boxebeld et al (1983) observed in 6-month old lambs fed semipurified diets that the negative effects of a P marginal deficiency (decreased phosphatemia and DMI) got worse when Ca was supplied to get a Ca:P ratio equal to 9.1:1. Also, Wan Zahari et al (1990) observed in wether lambs grown from 25 to $50 \mathrm{~kg} \mathrm{BW}$ that a Ca:P ratio of 3.6:1 had a negative effect on intake and growth rate when $\mathrm{P}$ was supplied at 0.75 times its requirement. All these references suggest that the proposed Ca:P ratio limits are acceptable if the minimum requirement of the companion mineral is met. In that respect, studies with 3-month old lambs have shown no negative effects when the diet supplies adequate $\mathrm{P}$ but $\mathrm{Ca}$ is in excess $(\mathrm{Ca}: \mathrm{P}$ 
ratio equal to 5.4:1; Rajaratne et al 1990), or when the diet supplies adequate $\mathrm{Ca}$ but $\mathrm{P}$ is in excess (Ca:P ratio equal to 0.5:1; Wan Zahari et al 1994).

\section{CONCLUSIONS}

Table 3 summarizes the nutrient limits applicable to optimize diets for growing goats through minimum cost linear programming. Energy requirements are expressed in relation to DMI and the rest of the nutrients are expressed in relation to energy.

Table 3. Nutrient and forage limits to formulate diets for growing goats through minimum cost linear programming.

Límites de nutrientes y forraje en la formulación de dietas para cabritas por programación lineal a mínimo coste.

\begin{tabular}{lcc}
\hline \multirow{2}{*}{\multicolumn{1}{c}{ Item }} & \multicolumn{2}{c}{ Limit } \\
\cline { 2 - 3 } & Minimum & Maximum \\
\hline Energy & Ereq:DMI ${ }_{\max }$ & Ereq:DMI ${ }_{\text {min }}$ \\
Metabolizable Protein & MPreq:Ereq & \\
Nitrogen:energy & PDIN:PDIE $\geq 1$ & \\
& DIP:TDN $\geq 0.09$ & \\
Neutral detergent fibre & & $30 \mathrm{~g} / \mathrm{kg}$ \\
& & $\mathrm{BW}^{0.75}: \mathrm{Ereq}$ \\
Acid detergent fibre & & $24-26 \% \mathrm{DM}$ \\
Calcium & Careq:Ereq & $1.5 \% \mathrm{DM}$ \\
Phosphorus & Preq:Ereq & $0.6 \% \mathrm{DM}$ \\
Calcium:phosphorus & Ca:P $\geq 1.2$ & Ca:P $\leq 7.0$ \\
Forage & $20 \mathrm{~g} / \mathrm{kg}$ & \\
& BW.75:Ereq \\
& or $20 \%$ DM \\
\hline
\end{tabular}

Careq, calcium requirements; DIP, rumen degradable protein; $\mathrm{DMI}_{\max }$ and $\mathrm{DMI}_{\min }$, maximum and minimum dry matter intake, respectively; Ereq, energy requirements expressed as milk fodder units $\left(\right.$ Ereq $\left._{\mathrm{UFL}}\right)$ or MJ of metabolizable energy $\left(\right.$ Ereq $_{\mathrm{ME}}$ ); PDIE and PDIN, protein truly digested in the small intestine when rumen available energy and rumen available nitrogen are limiting for microbial growth, respectively; Preq, phosphorus requirements; MPreq, protein requirements; TDN, total digestible nutrients. Minimum dry matter intake $\left(\mathrm{DMI}_{\min }\right)$ can be calculated as $1.1 \times$ Ereq $_{\mathrm{UFL}}$ or $0.09 \times \mathrm{Ereq}_{\mathrm{ME}}$, whereas maximum dry matter intake $\left(\mathrm{DMI}_{\max }\right)$ can be calculated as $1.5 \mathrm{x} \mathrm{Ereq}_{\mathrm{UFL}}$ or $0.12 \mathrm{x}$ Ereq $_{\mathrm{ME}}$ (from Leroy 1974; UFL/ME conversion factor is 7.11/0.59). DMI $_{\text {max }}$ should be decrease at least $10 \%$ in the last month of gestation.

Careq, necesidades de calcio; DIP, proteína degradable en rumen; DMI $_{\text {max }}$ y DMI ${ }_{\min }$, consumo máximo y mínimo de materia seca, respectivamente; Ereq, necesidades de energía expresadas como unidades forrajeras leche $\left(\right.$ Ereq $\left._{\mathrm{UFL}}\right)$ o MJ de energía metabolizable $\left(\right.$ Ereq $\left._{\mathrm{ME}}\right)$; PDIE y PDIN, proteína realmente digestible en el intestino delgado cuando la energía y el nitrógeno disponibles en rumen limitan el crecimiento microbiano, respectivamente; Preq, necesidades de fósforo; MPreq, necesidades de proteína; TDN, nutrientes digestibles totales. El consumo mínimo de materia seca $\left(\mathrm{DMI}_{\min }\right)$ puede calcularse como 1,1 x Ereq $_{\mathrm{UFL}}$ ó $0,09 \mathrm{x}$ Ereq $_{\mathrm{ME}}$, mientras que el consumo máximo de materia seca (DMI ${ }_{\max }$ ) puede calcularse como 1,5 x Ereq $\mathrm{UFL}_{\mathrm{UL}}$ ó 0,12 $\mathrm{x} \mathrm{Ereq}_{\mathrm{ME}}$ (a partir de Leroy 1974; el factor de conversión UFL/EM es 7,11/0,59). DMI ${ }_{\text {max }}$ debería reducirse al menos un $10 \%$ en el último mes de gestación.
Overall, data from the literature suggest that the maximum gut fill is reached when the diet contains about $30 \mathrm{~g} \mathrm{NDF} / \mathrm{kg} \mathrm{BW}^{0.75}$ or $24-26 \%$ ADF. The physiological limit of DMI is close to $12.55 \mathrm{MJ} \mathrm{ME} / \mathrm{kg}$. The minimum amount of forage to be provided by the diet should be 20 $\mathrm{g} / \mathrm{kg} \mathrm{BW}^{0.75} / \mathrm{d}$ or $20 \% \mathrm{DM}$. The use of the most recent feed evaluation systems -INRA (2007) and NRC (2007)to calculate the supply and requirements of energy and protein is not relevant since both provide similar values despite their different methodology. The decrease of diet digestibility due to inadequate available nitrogen in the rumen can be prevented easily by setting appropriate limits when optimizing diets. The requirements of $\mathrm{Ca}$ and $\mathrm{P}$ estimated according to different feed evaluation systems are quite different but the recommendations of Meschy $\left(2002^{\mathrm{a}}\right)$ are probably the most accurate. Calcium can be supplied in a large excess over its minimum requirements without any negative effect provided that the minimum requirement of $\mathrm{P}$ is met.

\section{SUMMARY}

Dry matter intake and nutrient requirements of young growing dairy goats were reviewed in this paper to derive nutrient limits applicable for diet optimization through minimum cost linear programming. The diets offered to growing goats should be optimized from both nutritional and economic view. To get those objectives, the nutritionist has to estimate accurately forage and total dry matter intake, and the nutrient supply and requirements. The reviewed literature suggests that intake of young growing goats ranges between physical and physiological limits imposed by gut fill and energy requirements. The filling effect of the diet is related to its structural carbohydrate content, whereas the physiological satiety effect is related to diet metabolizable energy content. The minimum intake of forage required to keep rumen health is low, whereas maximum forage intake is probably related to the neutral detergent fibre content of the total diet. The energy and protein supply and requirements calculated according to the two most recent feed evaluation systems are similar, what makes no difference using any of both to optimize diets. Recent proposals to calculate calcium and phosphorus supply and requirements provide greater accuracy than the older ones.

\section{REFERENCES}

AFRC, Agricultural and Food Research Council. 1993. Energy and protein requirements of ruminants. $\mathrm{CAB}$ International, Wallingford, UK.

AFRC, Agricultural and Food Research Council. 1998. The nutrition of goats. CAB International, Wallingford, UK.

ARC, Agricultural Research Council. 1980. The nutrient requirements of ruminant livestock. Commonwealth Agricultural Bureau, Farnham Royal, UK.

Bas P, P Morand-Fehr, P Schmidely. 1991. Weaning: a critical period for young kids. In: Morand-Fehr P (ed). Goat nutrition. European Association for Animal Production, Wageningen, The Netherlands, Pp 271-283.

Boxebeld A, L Gueguen, G Hannequart, M Durand. 1983. Utilization of phosphorus and calcium and minimal maintenance requirement for phosphorus in growing sheep fed a low-phosphorus diet. Reprod Nutr Dev 23, 1043-1053.

Brody S. 1926. Time relations of growth. I. Genetic growth constants of animals. J Gen Physiol 8, 233-251.

Brown LE, WL Johnson. 1985. Intake and digestibility of wheat straw diets by goats and sheep. J Anim Sci 60, 1318-1323. 
Conrad HR, AD Pratt, JW Hibbs. 1964. Regulation of feed intake in dairy cows. 1. Change in importance of physical and physiological factors with increasing digestibility. J Dairy Sci 47, 54-62.

CSIRO, Commonwealth Scientific and Industrial Research Organisation. 2007. Nutrient requirements of domesticated ruminants. CSIRO Publishing, Collingwood, Australia.

DLG, DLG-Futterwertabellenfür Wiederkauer. 2003. Recommendations for the supply of energy and nutrients to goats. DLG-Verlags-GmbH, Frankfurt am Main, Germany.

Fedele V, R Rubino, S Claps, G Morone. 2000. Effect of the physiological stage of dairy goats on intake frequency and feed preferences in a free-choice feeding system. In: Morand-Fehr P, I Ledin (ed). Seminar of the sub-network on nutrition of the FAO-CIHEAM inter-regional cooperative research and development network on sheep and goats. CIHEAM, Zaragoza, Spain, Pp 27-31.

Forbes JM. 2007. Voluntary food intake and diet selection in farm animals. $2^{\text {nd }}$ ed. CAB International, Wallingford, UK.

Freitas AR. 2005. Curvas de crescimento na produçao animal. $R$ Bras Zootec 34, 786-795.

Goetsch AL, G Detweiler, T Sahlu, J Hayes, R Puchala. 2003. Effects of separate offering of forage and concentrate on feed intake and growth of Alpine doelings. Small Rumin Res 48, 209-216.

Hadjipanayiotou M, P Morand-Fehr. 1991. Intensive feeding of dairy goats. Goat nutrition. European Association for Animal Production, Wageningen, The Netherlands, Pp 197-208.

Hooper AP, JG Welch. 1983. Chewing efficiency and body size of kid goats. J Dairy Sci 66, 2551-2556.

Hvelplund T, J Madsen. 1993. Protein systems for ruminants. Icel Agr Sci 7, 21-36.

INRA, Institut National de la Recherche Agronomique. 1978. Alimentation des ruminants. INRA Éditions, Paris, France.

INRA, Institut National de la Recherche Agronomique. 1988. Alimentation des bovins, ovins et caprins. INRA Éditions, Paris, France.

INRA, Institut National de la Recherche Agronomique. 2002. Tables de composition et de valeur nutritive des matières premières destinées aux animaux d'élevage. INRA Éditions, Paris, France.

INRA, Institut National de la Recherche Agronomique. 2007. Alimentation des bovins, ovins et caprins. Éditions Quae, Paris, France.

Leroy AM. 1974. Cría racional del ganado. $3^{\text {a }}$ edición. Ediciones Gea, Barcelona, España.

Liesegang A, J Risteli. 2005. Influence of different calcium concentrations in the diet on bone metabolism in growing dairy goats and sheep. J Anim Physiol Anim Nutr 89, 113-119.

Lu CD, MJ Potchoiba. 1990. Feed intake and weight gain of growing goats fed diets of various energy and protein levels. J Anim Sci 68, 1751-1759.

Lu CD, JR Kawas, OG Mahgoub. 2005. Fibre digestion and utilization in goats. Small Rumin Res 60, 45-52.

Luo J, AL Goetsch, IV Nsahlai, JE Moore, ML Galyean, ZB Johnson, T Sahlu, CL Ferrell, FN Owens. 2004. Voluntary feed intake by lactating, Angora, growing and mature goats. Small Rumin Res 53, 357-378.

Martínez Marín AL. 2007. Alimentación de cabritas de reposición (I). Mundo Ganadero 201, 44-48.

Martínez Marín AL. 2009. NRC e INRA para raciones de caballos de ocio basadas en forrajes secos y concentrados granulados. Arch Zootec 58, 333-344.

Martínez Marín AL, M Pérez Hernández, L Pérez Alba, G Gómez Castro. $2010^{a}$. Repercusión del sistema de valoración energética sobre el coste de raciones para vacas lecheras. REDVET 11, 1-14.

Martínez Marín AL, M Pérez Hernández, L Pérez Alba, AG Gómez Castro. 2010 . Choosing a feed evaluation system: NRC vs. INRA to formulate rations for growing goats using minimum cost linear programming. J Anim Feed Sci 19, 525-538.

Masson C, R Rubino, V Fedele. 1991. Forage utilization in goats. In: Morand-Fehr P. (ed). Goat nutrition. European Association for Animal Production, Wageningen, The Netherlands, Pp 145-159.
McDonald I, JJ Robinson, C Fraser. 1979. Studies on reproduction in prolific ewes. 5. The accretion of nutrients in the foetuses and adnexas. J Agr Sci (Cambridge) 92, 591-603.

Mejía-Haro I, DR Brink, J Fajardo, B Ortíz. 2001. Effects of different $\mathrm{Ca}: \mathrm{P}$ ratios in lamb diets on apparent absorption and retention of phosphorus. Agrociencia 35, 497-502.

Meschy F. 2002 ${ }^{\mathrm{a}}$. Mineral nutrition (macro-elements) : recent progress in goats. INRA Prod. Anim 15, 267-271.

Meschy F. 2002 ${ }^{\text {b }}$. Recommandations d'apport en phosphore absorbé chez les ruminants. Renc Rech Ruminants 9, 279-285.

Meschy F, R Corrias. 2005. Recommandations d'apport alimentaire en calcium et magnésium absorbables pour les ruminants. Renc Rech Ruminants 12, 221-224.

Mohr GM. 1972. The bulk constraint and computer formulations of least-cost feed mixes. Rev Market Agr Econ 40, 15-28.

Montgomery MJ, BR Baumgardt. 1965 . Regulation of food intake in ruminants. 1. Pelleted rations varying in energy concentration. $J$ Dairy Sci 48, 569-574.

Montgomery MJ, BR Baumgardt. 1965 . Regulation of food intake in ruminants. 2. Rations varying in energy concentration and physical form. J Dairy Sci 48, 1623-1628.

Negesse T, M Rodehutscord, E Pfeffer. 2001. The effect of dietary crude protein level on intake, growth, protein retention and utilization of growing male Saanen kids. Small Rumin Res 39, 243-251.

NRC, National Research Council. 1980. Mineral tolerance of animals. National Academy Press, Washington DC, USA.

NRC, National Research Council. 1981. Nutrient requirements of goats. National Academy Press, Washington DC, USA.

NRC, National Research Council. 2000. Nutrient requirements of beef cattle. Update 2000. National Academy Press, Washington DC, USA.

NRC, National Research Council. 2001. Nutrient requirements of dairy cattle. 7 th rev. ed. National Academy Press, Washington DC, USA.

NRC, National Research Council. 2005. Mineral tolerance of animals. $2^{\text {nd }}$ rev. ed. National Academy Press, Washington DC, USA.

NRC, National Research Council. 2007. Nutrient requirements of small ruminants. National Academy Press, Washington DC, USA.

Owens FN, P Dubeski, CF Hanson. 1993. Factors that alter the growth and development of ruminants. J Anim Sci 71, 3138-3150.

Prieto I, AL Goetsch, V Banskalieva, M Cameron, R Puchala, T Sahlu, LJ Dawson, SW Coleman. 2000. Effects of dietary protein concentration on postweaning growth of Boer crossbred and Spanish goat wethers. J Anim Sci 78, 2275-2281.

Rajaratne AAJ, D Scott, JK Thompson, S Buchan, K Pennic. 1990. The effect of variation in dietary calcium supply on the phosphorus requirements of growing lambs. Anim Prod 51, 135-142.

Randy HA, JF Heintz, DL Lynch, CJ Sniffen. 1984. Protein, fibre, and mineral nutrition of growing dairy goats. J Dairy Sci 67, 2974-2977.

Robinson JJ, I McDonald, C Fraser, RMJ Crofts. 1977. Studies on reproduction in prolific ewes. I. Growth of the products of conception. J Agr Sci (Cambridge) 88, 559-552.

Schinckel AP, DC Mahan, TG Wiseman, ME Einstein. 2008. Impact of alternative energy systems on the estimated feed requirements of pigs with varying lean and fat tissue growth rates when fed corn and soybean meal-based diets. Prof Anim Sci 24, 198-207.

Soto-Navarro SA, AL Goetsch, T Sahlu, R Puchala, LJ Dawson. 2003. Effects of ruminally degraded nitrogen source and level in a high concentrate diet on site of digestion in yearling Boer x Spanish wether goats. Small Rumin Res 50, 117-128.

Soto-Navarro SA, AL Goetsch, T Sahlu, R Puchala. 2004. Effects of level and source of supplemental protein in a concentrate-based diet on growth performance of Boer x Spanish wether goats. Small Rumin Res 51, 101-106.

Susmel P, M Spanghero, CR Mills. 1989. Intensification of cattle milk production in Mediterranean countries: low forage systems. Options Méditerranéennes 6, 79-90.

Urge M, RC Merkel, T Sahlu, G Animut, AL Goetsch. 2004. Growth performance by Alpine, Angora, Boer and Spanish wether goats consuming 50 or $75 \%$ concentrate diets. Small Rumin Res 55, 149-158.

Voicu I, G Burlacu, RD Criste, D Voicu. 1993. Study on the energy and protein requirements in goats. Arch Anim Nutr 44, 47-61. 
Wan Zahari M, JK Thompson, D Scott, W Buchan. 1990. The dietary requirements of calcium and phosphorus for growing lambs. Anim Prod 50, 301-308.

Wan Zahari M, D Scott, N Loveridge, W Buchan, J Milne. 1994.

The effect of high phosphorus intake on calcium and phosphorus retention and bone turnover in growing lambs. Exp Physiol 79, 175-181.

Williams CB, PA Oltenacu, CJ Sniffen. 1989. Application of neutral detergent fibre in modelling feed intake, lactation response, and body weight change in dairy cattle. J Dairy Sci 72, 652-663. 